\title{
Project ACTIVate: Innovations from New Zealand
}

\author{
Janet Yelas and Paul Engles \\ St Mary's School, New Zealand
}

\begin{abstract}
This case study discusses a collaborative three year project involving two school clusters located in the North Island and South Island of New Zealand. The project was named Project ACTIVate and its main thrust was to study how the use of the interactive whiteboard (IWB) combined with teaching, learning and research across schools. The project was also partnered with the Ministry of Education, New Zealand, a tertiary institution, and information and communication technology-related and enterprises. The aim of the research was to develop effective teaching and learning practices using IWB technology in New Zealand classrooms. It was also deemed significant for the project to use the IWB to enhance specific curriculum goals and environments where students and teachers could learn and research as partners in cognitive proximity within schools and across schools. A number of successes and challenges presented themselves during the three year time frame. One aspect of particular importance for education arising from the case study is the future implications for IWB technologies.
\end{abstract}

\section{Introduction}

Project ACTIVate was a collaborative project involving two school clusters located in the North Island and South Island of New Zealand respectively and took place over three years, 2005 to 2007. It was one of a series of the New Zealand Ministry of Education (MoE) (2001) Digital Opportunities Projects. These projects are joint partnership initiatives between the New Zealand Ministry of Education, New Zealand schools and universities and information and communication technology related enterprises. The mission of the Digital Opportunities initiatives has been to support schools in the innovative use of information and communication technologies (ICT) through partnership ventures, thereby promoting an overall aim of improving teaching and learning through the use of leading edge technologies. The first part of this article details the Project ACTIVate case study in the context in which research was carried out within the North Island and South Island schools. Then within the larger Project ACTIVate context, the second part of the article details an individual school's experience of the convergence of the interactive whiteboard (IWB) technology and pedagogy.

\section{The Project ACTIVate context}

Project ACTIVate was one of the Digital Opportunities initiatives and its main thrust was the use of the IWB technology combined with teaching, learning and research across schools. The use of this technology has been critical to the enhancement of collaborative, distance and inquiry based teaching and learning. The scene was set at the official launch of Project ACTIVate in 2005 where the strategic importance of utilising new educational technologies such as IWBs to create high quality interactive 
learning for children throughout New Zealand was recognised by the Prime Minister at the time, Helen Clark. At the launch of this initiative, the potential of IWBs was demonstrated in a science lesson on flotation. Students from Southland Girls' High School (a South Island secondary school) delivered an interactive lesson to children at St Mary's School (a primary school in Auckland, North Island) via web conferencing using IWBs. The students in both the North Island and South Island 'could see and hear one another and were able to control objects on the IWB to carry out a series of experiments to determine which objects would sink and which would float' (Duncan, Dysart, Ryba \& Edwards, 2005; p. 20).

\section{Literature informing Project ACTIVate}

Within the ICT research, there is a growing body of research on IWBs and in recent times there has been an increasing awareness for the need to understand how to match pedagogy to technology, particularly the salient pedagogical notion of matching interactivity between the students and technology. In New Zealand, the Ministry of Education (MoE) (2006) argues that pedagogy and technology can converge and it also maintains that schools should explore not only how ICT can supplement traditional ways of teaching but also how it can innovate different ways of learning. In some cases unfortunately, the IWB has been seen predominantly as a teaching tool rather than a learning vehicle to be driven by students. Some research suggests that 'rather than transforming teacher's pedagogy, the interactive whiteboard can be relatively easily assimilated into existing ways of working' (Armstrong, Barnes, Sutherland, Curran, Mills \& Thompson, 2005; p. 458). However, in New Zealand, Project ACTIVate (Engles, Cairns, Lane, Scott \& Yelas, 2005) demonstrated that the learning communities created in the IWB context were communities of practice where students took part in legitimate peripheral participation (Lave \& Wenger, 1991), moving then to full social interactivity and participation.

A great deal of attention worldwide has been given to using evidence in teaching practice. In the past, many teaching methods and approaches have been adopted on the basis that they are good and useful. Recently however, there has been a call for evidence to confirm what works in teaching practice, why it works and how it works. Therefore, because of the endorsement by the MoE (2006) to open up new and different ways of learning, the partnership decided to adopt the research from the best evidence synthesis written for the MoE by Alton-Lee (2003) as it was deemed to be a firm foundation for developing each school's research project. The best evidence synthesis 'has produced ten characteristics of quality education derived from a synthesis of research findings of evidence linked to student outcomes' (Alton-Lee, 2003; p. v). So the participating schools were to be informed by principles and practices shown to be effective for quality teaching and learning (Alton-Lee, 2003) and to combine them in the IWB context. This perspective fitted very well with Glover and Miller's (2009) notion that the learning process and outcomes can be enhanced by the effective use of IWBs.

\section{The collective partnership of Project ACTIVate}

The collective partnership of Project ACTIVate included:

- North Island and South Island School Clusters that were currently utilising interactive whiteboard technology in a variety of learning areas for meeting curriculum goals, plus the teachers and students from those schools; 
- Participants from Massey University, College of Education, Albany Campus, Auckland who were experienced in ICT project facilitation, administration and evaluation;

- Venture Southland, an economic, community development organisation involved in promoting new learning and teaching technologies in schools; and

- Envision Presentations, an ICT business which supplied the IWB technology and training to schools.

\section{The rationale for Project ACTIVate}

The collective partnership worked initially towards three goals and these are listed as:

1. To develop New Zealand classroom/school based models of effective learning and teaching practice using IWB technology to achieve specific curriculum goals;

2. To explore how an IWB could enhance an environment which supports the development of the notion of student-teacher partnership; and

3. To create caring, inclusive and cohesive learning communities within schools and across schools, particularly across long distances.

However, by the third year of the project the objectives became more defined and are listed as:

1. To use multi-faceted pedagogical practices aligned with Characteristics of Quality Teaching (Alton-Lee, 2003) and to integrate the IWB as a cognitive tool for these pedagogical practices;

2. To develop an environment in which students and teachers could learn and research as partners in cognitive proximity within schools and across schools; and

3. To create a cohesive learning community within each individual school and also across the North Island and South Island Schools.

All schools had similar technology infrastructure. However, the IWB was the major technological tool and this was complemented with a variety of other hardware and software. The following infrastructure included all the following technologies and interactive communication at some time in the research:

- The IWB was used significantly in all the classrooms involved in the study, as were digital cameras and video cameras;

- There was a facilitation of interactive communication between the two school clusters, that is the North Island Cluster and the South Island Cluster;

- Simultaneous video, voice, IWB, text, and browser communication were used; and

- Communication across schools was carried out with Elluminate Live $(2006,2007)$ web conferencing.

Alton-Lee's (2003) research synthesis provided a useful framework for the professional development of Project ACTIVate teachers. The Project ACTIVate team coupled this framework with an action research approach in order for teachers to gather evidence in a systematic way on the multi-faceted pedagogical practices used in the IWB environment. The action research approach was seen as a way to give the research some uniformity and validity across both islands in New Zealand. Therefore, the main thrust for professional development for the teachers of Project ACTIVate was to develop the best methods for creating better learning conditions in the classroom with IWBs and to inform individual teaching practice (Timperley \& Parr, 2004). 
A conceptual model for Project ACTIVate was devised as a framework which would give uniformity to the research. This conceptual model was formulated by Duncan et al. (2005; p. 7) and is outlined in Figure 1.

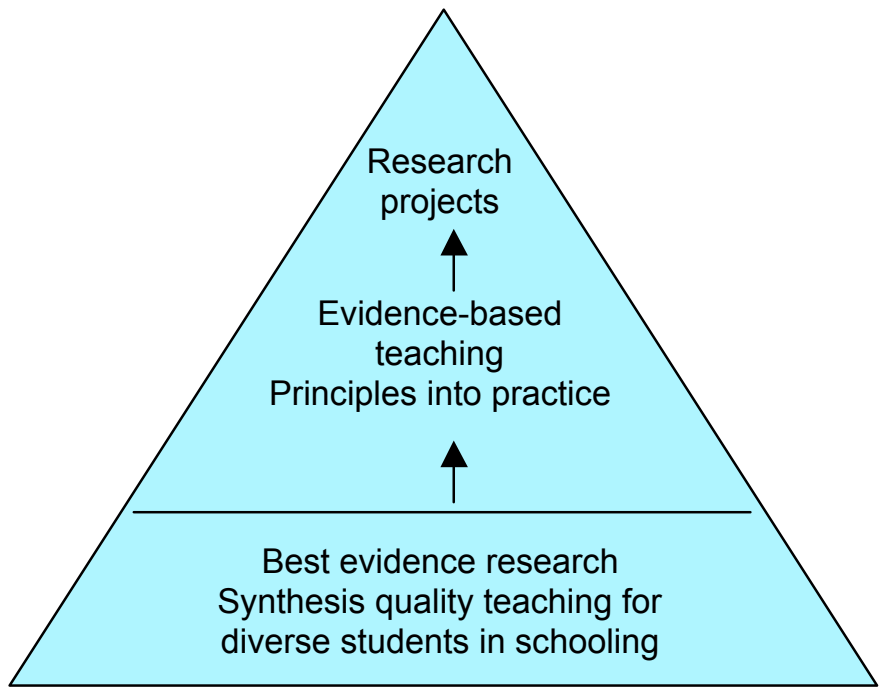

Figure 1: A conceptual model for Project ACTIVate

\section{Action research}

There are four stages in action research which create a research cycle. The four stages (planning, implementing, observing, reflecting) are set out in Figure 2.

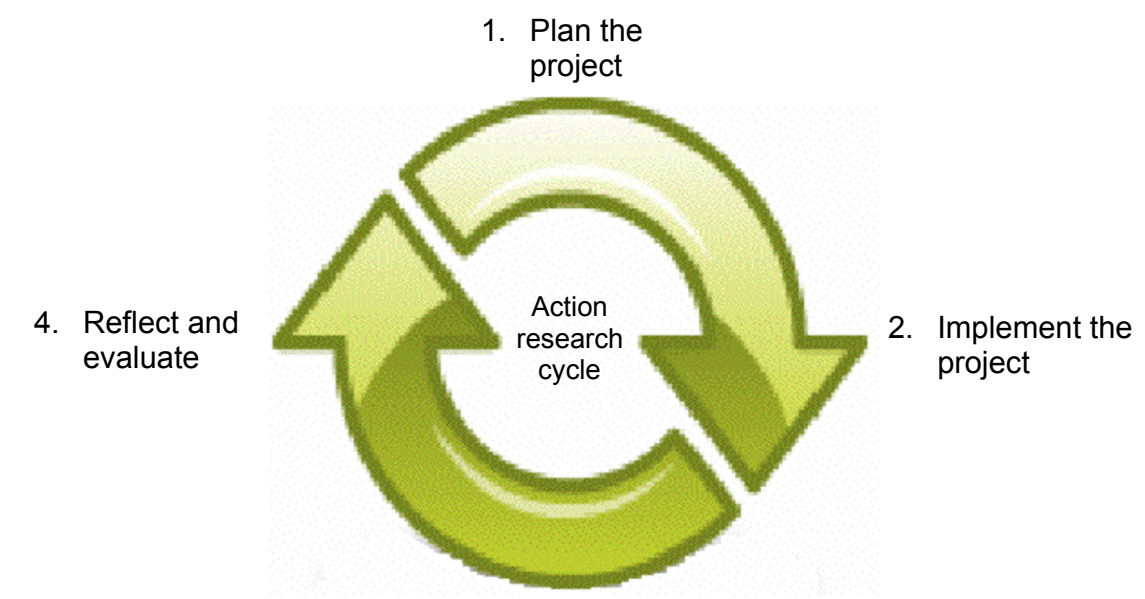

3. Observe the project

Figure 2: The action research cycle detailing the four step cycle

According to Kemmis and McTaggart (1988) action research is a cyclical and continuous process. These stages are not separate but are embedded within action and 
reflection. Short, multiple cycles allow greater rigour to be achieved. Traditional experimental research tends to be contrived and seeks to control intervening variables. In contrast, action research can be carried out within the everyday context of the classroom and seeks to study important dimensions of the learning environment within real life situations. It is the integrated cycle of activities that unites action research's 'two central concerns - improvement in practice and increased knowledge and understanding' (Winter, 1989; p. 11).

Utilising the action research cycle, schools planned, implemented, observed and evaluated their own projects with support from their academic and business partners.

\section{Evaluation and assessment criteria used}

In action research most of the data collected is of the qualitative type. So for this approach to be valid, a wide range of data and information was required. Therefore it was the aim of Project ACTIVate to gather a range of data and information 'in many different ways so that results could be triangulated in order to confirm outcomes' (Duncan et al. 2005; p. 9). Triangulation encouraged the use of careful and systematic analysis of the data to verify the outcomes.

Some or all of the following examples were collected:

- Observation and analysis were used as a way to consider the practice and alignment of multi-faceted pedagogical practices. This could include multi-modal presentations such as written, oral and visual presentations, for example Flipcharts and PowerPoints;

- Narrative analysis of the way students and teachers were engaged in learning and teaching with IWBs;

- Rubric assessments undertaken by students and teachers to gauge their social interactions and collaboration;

- Rubric self assessments undertaken by students and teachers to gauge their cognitive learning, such as using their thinking skills and learning strategies; and

- Surveys of students which identified their perceptions and experiences with IWB use.

\section{Data examples}

In all schools, data gathering was undertaken throughout the cycles and the data gathering record included observations, surveys, digital photos and videos and self assessment rubrics. All these could be used for ongoing evaluation and reflection within each school and across the schools in both the North and South Islands.

\section{Rubrics}

Rubrics were used because they were useful for assessing complex performances. Students and teachers could work together to develop a rubric which communicated clearly the intention of assessment. According to Jonassen, Howland, Morre and Marra (2003), the rubric has to do three things:

- Promote intentional learning by identifying important aspects of the performance;

- Enable reflection on the performance and guide students though the learning process; and 
- Encourage participants to explain their reasoning about their score for the performance.

A number of different rubrics were specifically developed by teachers and students themselves or by using Rubistar for Teachers (2007).

The sample in Table 1 was developed specifically in Rubistar for Teachers for the Project ACTIVate research by one of the authors. This rubric was typical of an authentic self assessment used by both students and teachers. The rubric took into account how students were increasing their knowledge and was scored from one to four with one being the lowest score.

Table 1: The rubric of self-assessment about knowledge construction

\begin{tabular}{|c|c|c|c|c|}
\hline \multirow{2}{*}{$\begin{array}{l}\text { Constructing new } \\
\text { knowledge in the } \\
\text { IWB setting }\end{array}$} & 4 & 3 & 2 & 1 \\
\hline & $\begin{array}{l}\text { I can use the IWB } \\
\text { in different ways } \\
\text { to help me } \\
\text { understand and } \\
\text { explain all of the } \\
\text { following terms: } \\
\text { Biodiversity; } \\
\text { Insecurity; } \\
\text { Economic issues; } \\
\text { Social issues; and } \\
\text { Future planning. I } \\
\text { can make a } \\
\text { generalisation } \\
\text { about the terms. }\end{array}$ & $\begin{array}{l}\text { I can use the IWB } \\
\text { in different ways } \\
\text { to help me } \\
\text { understand and } \\
\text { explain three of } \\
\text { the following } \\
\text { terms: } \\
\text { Biodiversity; } \\
\text { Insecurity; } \\
\text { Economic issues; } \\
\text { Social issues; and } \\
\text { Future planning. }\end{array}$ & $\begin{array}{l}\text { I can use the IWB } \\
\text { in different ways } \\
\text { to help me } \\
\text { understand two } \\
\text { of the following } \\
\text { terms: } \\
\text { Biodiversity; } \\
\text { Insecurity; } \\
\text { Economic issues; } \\
\text { Social issues; and } \\
\text { Future planning. }\end{array}$ & $\begin{array}{l}\text { I can use the IWB } \\
\text { in different ways } \\
\text { to help me } \\
\text { understand one } \\
\text { of the following } \\
\text { terms: } \\
\text { Biodiversity; } \\
\text { Insecurity; } \\
\text { Economic issues; } \\
\text { Social issues; and } \\
\text { Future planning. }\end{array}$ \\
\hline
\end{tabular}

\section{Photos}

Photos and the collection of anecdotal material also gave further examples of multifaceted pedagogical practices used in the IWB environment and how students performed in the role of partnership with the teachers.

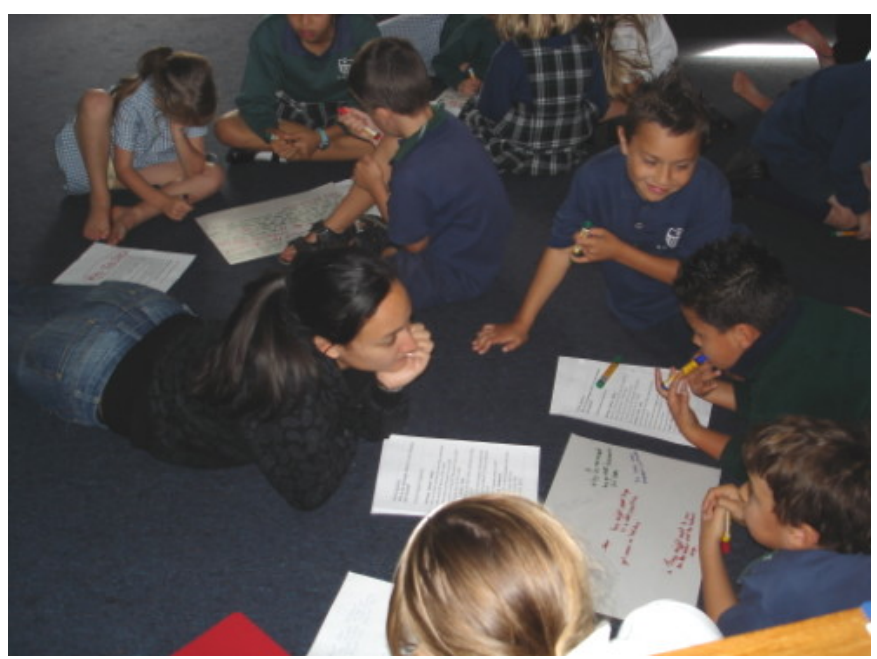

Figure 3: The teacher is a participant in the group 
The students and teachers in Figure 3 are using Flipcharts and information printed from the IWB and it is difficult to see the teacher at first glance.

\section{Surveys}

Surveys allowed teachers to examine carefully how students perceived their learning and collaboration. An example of a typical survey and recorded answers in Table 2 indicated not only how the students viewed the notion of working in a student-teacher partnership, but also how students viewed the cognitive aspects of their own learning with regard to questioning, learning and thinking. The examples in Table 2 demonstrate the students' actual words about their learning processes and how they perceive their interaction with teachers and an IWB.

Table 2: A typical example of the survey

\section{Survey about the IWB}

Q. In what way does the IWB help you to find out information?

We can get information from Google Earth / Internet.

Q. In what way does the IWB help you to make up your questions?

The words on the IWB Flipcharts help me to think up the questions.

All the different things that are on the ACTIVboard give you clues.

Q. In what way does the IWB to help you to learn?

Brainstorming on a Flipchart help give us ideas and they can be saved.

We learn by looking at the different things on the IWB.

The IWB helps me to learn by giving simple, easy instructions on how to start or finish.

If we research something and save it on a Flipchart, the whole class can engage and be involved.

You learn from the IWB because you can use it in a group and everyone can share opinions.

Q. In what way does the IWB help you to think?

You interact with the IWB and it helps you to think.

The IWB helps me know something I didn't know before.

It helps you think by putting information in your head.

Q. What has it been like to be with teachers who have been learning with you?

The teachers teach us and we teach them.

My teacher learns by using the IWB.

The teachers discovered answers to questions just like us.

It's interesting that the teacher doesn't know things.

We learn with the teachers by talking and showing each other what to do.

It's fun to learn with the teachers.

It's fun learning with the teachers because they're teachers and we can be teachers too because we teach them new things. 


\section{St Mary's School: An individual school case study}

The Project ACTIVate approach was significant for St Mary's School as the school extolled the use of multi-faceted pedagogical practices. At St Mary's School, the inquiry based approach was further guided and informed by the underlying concepts of the school's own Thinking Curriculum (Engles et al., 2005; p. 15). The Thinking Curriculum in Table 3 is based on ideas of Harpaz (2003) who promotes thinking as a multifaceted cognitive activity involving social, conceptual, linguistic, emotional, motivational, physical and other dimensions.

Table 3: The Thinking Curriculum designed by the authors for St Mary's School (Engles, Cairns, Lane, Scott \& Yelas, 2005).

\begin{tabular}{|c|c|c|}
\hline \multicolumn{3}{|c|}{$\begin{array}{l}\text { St Mary's Thinking Curriculum } \\
\text { (Alignment with PBL, NZ Curriculum, information } \\
\text { retrieval processes and facilitatory environments) }\end{array}$} \\
\hline $\begin{array}{c}\text { Problem based learning } \\
\text { and information retrieval } \\
\text { processes } \\
\text { DEFINE } \\
\text { Authenticate the learning } \\
\text { Awaken prior knowledge } \\
\text { Construct relevant questions } \\
\text { LOCATE } \\
\text { Plan the research }\end{array}$ & $\begin{array}{c}\text { NZ Curriculum } \\
\text { An integrated approach } \\
\text { Aims and objectives from the } \\
\text { NZ Curriculum documents } \\
\text { Inquiry } \\
\text { Fertile questions } \\
\text { Subsidiary questions / } \\
\text { hypotheses using } \\
\text { Structured Overview of } \\
\text { Student Outcomes (SOLO) } \\
\text { (Biggs \& Collis, 1982) } \\
\text { Goal setting/rubrics } \\
\text { established } \\
\text { Design and tools / data } \\
\text { collection } \\
\text { Analyses/rubrics } \\
\text { Conclusion } \\
\text { Review objectives / reflection } \\
\text { Assessment and evaluation } \\
\text { Performativity: A } \\
\text { CONCLUDING } \\
\text { PERFORMANCE }\end{array}$ & $\begin{array}{c}\text { Facilitatory environments } \\
\text { context: } \\
\text { Student centred } \\
\text { ICT/IWB } \\
\text { Construction: } \\
\text { Knowledge } \\
\text { construction } \\
\text { Collaboration: } \\
\text { Pairs/groups/class } \\
\text { Communication: } \\
\text { Conversation/ } \\
\text { dialogue } \\
\text { Information: } \\
\text { ICT/ libraries/ } \\
\text { experts/ facilitators }\end{array}$ \\
\hline
\end{tabular}

This Thinking Curriculum demonstrates how problem based learning (PBL), an inquiry based approach, links with the New Zealand Curriculum achievement objectives and the facilitatory environments. The columns run concurrently and the central column leads to a Concluding Performance which brings all the teaching and learning together.

\section{The teaching and learning process}

During each year of the project, St Mary's School gave particular consideration to the setting, the sample, the time line, pedagogical approach, data gathering phases and methods, and then finally to the analysis and evaluation of the study. 


\section{Sample, setting and time line}

The sample consisted of a group of 18 student participants from four different learning areas. The group comprised of 6, 7, 11 and 12 year old students who formed a vertical group. The principal of the school chose the student participants as a purposive group. This purposive group was chosen on his judgment of the typicality of the students to the research (Cohen \& Manion, 1994). The principal and three teachers were also participants in the research. Most of the lessons took place in a classroom with an IWB. All participants, teachers and students met once a week over a period of three terms.

\section{Pedagogical approach}

The pedagogical approach took into account the multi-faceted dimensions of teaching and learning but used particularly both a problem based learning perspective and an information processing perspective. St Mary's School's own thinking curriculum designed by the authors (Engles et al., 2005)) played a major role in the research and was used from 2005 through to 2007.

Project ACTIVate encouraged the integration of different disciplines of the New Zealand Curriculum. For example, in 2007 the theme was Tourism and this arose initially from the discipline of Social Sciences but included five overarching areas of focus, namely Biosecurity, Biodiversity, Social issues, Economic issues and Future planning which also related to other disciplines. The research project drew also on authentic situations such as interviewing by Polycom and having experts visit the classroom. Gabel (1999) has concluded that there is strong research support for the use of real life situations to assist students to learn, and to make transparent meaningful connections between classroom learning and real life applications. The planning acknowledged the notion that each student would bring their own world view to the research and that by using multi-modal ways of obtaining information each student would be able to construct new knowledge. The IWB was seen as the tool ideal for students to provide opportunities for gathering data, for formulating the information, for sharing information and for reflecting on the information gathered.

\section{Data gathering methods and phases}

Different data gathering methods were undertaken throughout the cycles and the observational record included observations, pre and post surveys, digital photos and videos and a rubric for self assessment. The rubric provided some hard data which complimented a range of qualitative data. Especially pertinent qualitative data were the type of comments given in the survey. All this information was used for ongoing evaluation and reflection and as evidence for overall teacher judgements about the optimisation for student learning.

Table 4: The rubric results of self assessment about knowledge construction ( $\mathrm{N}=18$ students)

\begin{tabular}{|c|c|c|c|c|c|c|c|}
\hline \multicolumn{8}{|c|}{ Co-learning in a group using an IWB: Rubric result } \\
\hline \multicolumn{2}{|c|}{4} & \multicolumn{2}{|c|}{3} & \multicolumn{2}{|c|}{2} & \multicolumn{2}{|c|}{1} \\
\hline $\mathrm{n}$ & $\%$ & $\mathrm{n}$ & $\%$ & $\mathrm{n}$ & $\%$ & $\mathrm{n}$ & $\%$ \\
\hline 4 & 23 & 9 & 50 & 3 & 16 & 2 & 11 \\
\hline
\end{tabular}




\section{Analysis and evaluation}

One of the aims of the analysis was to find out to what extent the students and teachers were learning in partnership and how the IWB supported that partnership. A critical aspect of the PBL approach and the school's Thinking Curriculum was that the students had to present a concluding performance to an audience of parents and invited guests. This exercise was a joint teaching and learning effort for all participants. It was noticeable that PBL engaged participants in interdisciplinary exploration, collaborative activity and field based opportunities for experiential learning, as well as reflection and examination (Kroll \& Laboskey, 1996) and that the participants found that the IWB supported this type of learning context. This fact was supported in the results of the rubric set out in Table 4, in which $73 \%$ of students scored themselves at three and four respectively, both being at the higher end of the scale. It was also evident that the participants used multi-modal approaches to learning and presenting. For example, it was observed that to create their final concluding performances the students used:

- a range of software on the IWB and the computer such as Flipcharts and PowerPoints; and

- a range of hardware such as the Polycom, digital camera/video and the microphone.

The presentations of the students were multi-modal and encompassed different aspects of:

- drama, sport, interviews, different disciplines and different modes of language and art.

The students drew on information from:

- experts, the teachers, other students and the Internet.

\section{Learning outcomes and findings of the project}

\section{Successes}

At St Mary's School over the three years, teachers observed many forms of students' participation. Teachers became cognisant about bringing together curricular resources and pedagogical strategies that exposed 'students to different mental strategies, multiple metacognitive tools, competing world-views and the diversity of the curriculum' (Alton-Lee, 2003; p. 69) and they saw the IWB context as a way to enhance mental strategies to optimise student learning. The use of the IWB afforded the students a rich diversity of perspectives and resources which could be combined and used with the more traditional sources of sourcing information.

The teachers believed that the IWB environment did provide a context for the development of student-teacher partnerships and over the time of the research the group did indeed become a learning community in action (Ryba, 2005). In fact this community had something to offer other students, teachers and parents as they shared their findings to the larger community. A unique dimension of Project ACTIVate was the attention given to active participation of students in the research process and to the formation of learning communities of practice (Lave \& Wenger, 1991). Particular emphasis was placed on the concept of creating caring, inclusive and cohesive learning communities within the schools and across the country. The IWB created a context for the development of this type of community, a context where dialogue about 
interactivity, collaboration, creativity, knowledge construction and reflection took place (Jonassen, Peck \& Wilson, 1999). It is particularly important to note that action research was an ideal vehicle for the methodology as the four step cycle could be understood and followed by both teachers and students.

A particular development in the community of practice was the participatory role taken by both students and teachers as they learned to use the IWB together. The IWB became a vehicle for co-learning, student to student, teacher to student and teacher to teacher, enabling interactivity on a number of levels. This participatory interactivity endorsed the role of students as co-researchers. According to Fielding and Bragg (2003), students in the role students as researchers or co-researchers are seen as significant agents of change, not just collectors of information for other people.

At a national level, multi-modal ways of teaching and learning were recognised by students and teachers in both the North Island and South Island School Clusters. Multi-modal literacies in language and text are very much supported by $3 \mathrm{D}$ visual symbols such as images, graphs and diagrams (Gilbert, 2005) and for this the IWB was ideally suited (Figure 4). The action research method proved to be a uniform method for all schools over the three years as it gave a common framework. Participants in both the North Island and South Island clusters were able to share similar experiences of some unique elements with regards to the convergence of IWB technology and pedagogy. These experiences covered a number of levels: personal; participative; evidenced based; and reflective level.

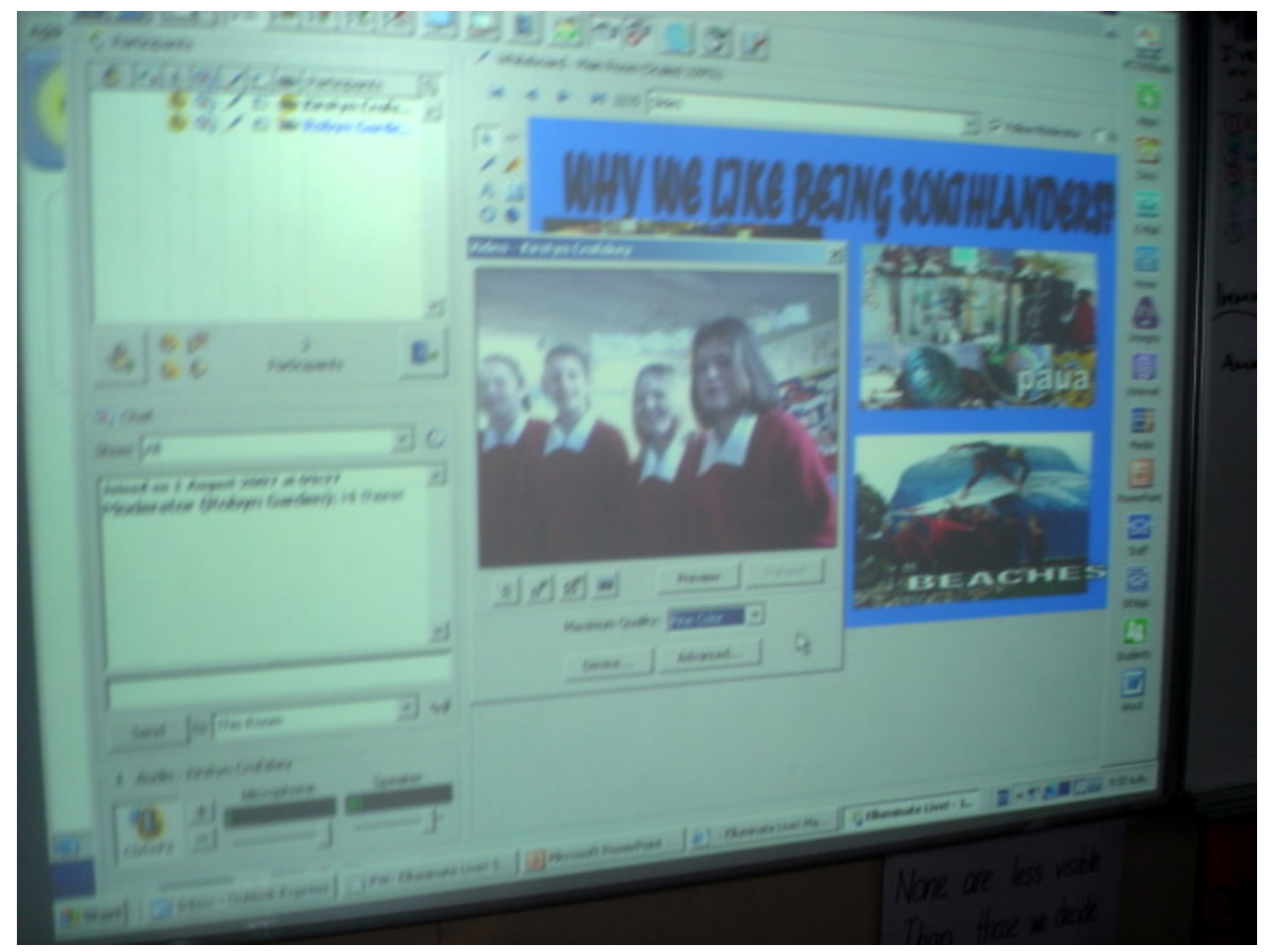

Figure 4: A view of a PowerPoint on the IWB coming live from the South Island to the North Island 


\section{Challenges}

As always, there was never enough time allocated for teachers take part in this type of research in schools. This was inevitable because most teachers still had their regular class to run. The success of the research was reliant on the passion of teachers who wanted success for the students. Success also relied on the good will of other teachers who lent their teaching space and time for accommodating other students. Therefore, for this type of research to take place, the continuing challenge relating to logistics and organisation remains. Also, to reduce the levels of frustration the equipment needs to be robust enough to give fast ease of access when required between IWBs on a local, national and global level.

The importance of the facility for students and teachers to communicate globally in realtime has to be recognised at a Ministry and Government level. However, there are still logistical issues to have this realtime learning and teaching run smoothly. Project ACTIVate did achieve some excellent link ups, but always there were a number of technicians involved who had to solve problems such as communication delays.

\section{Future implications}

Project ACTIVate, the New Zealand Ministry of Education Digital Opportunities (2001) Cluster drew to an end in 2007. However many important implications for the IWB environment presented themselves and teachers continue to develop teaching and learning practices in their schools. Teachers are becoming more aware of technological opportunities and recognise the multi-faceted nature of the IWB for teaching and learning and also that the IWB can be used in a multi-disciplinary way. It should also be acknowledged that the interactiveness of the participants is as important if not more so than the interactiveness of the IWB. Over the duration of the three years it became noticeable that the multi-faceted pedagogical approaches and perspectives had been the driving forces in this research. The IWB was not centre stage but rather it was an interactive tool which allowed things to happen. Whether it is a social tool or a cognitive tool (Mehan, 1989) makes little difference. The fact that some local and national dialogue took place, some higher order thinking was demonstrated and some self reflection was used by both students and teachers proved that the IWB created a context in which these aspects could happen.

In this global society we need to be cognisant of the opportunities for maximising student outcomes. Therefore, perhaps one of the possibilities for the IWB going forward is the opportunity to use it as a tool to connect learning communities around the world thus, setting in place a global learning community. As stated previously, IWB functionality has been successfully used to link together students and teachers across distance nationally. The furthering of this function to include students from around the globe will raise the student and teacher voice in the future creation of our world. Harmonising differing world views, sharing learning across many contexts and communities will only enhance the possibilities for the good of our future world.

\section{Conclusion}

The teacher participants agreed that an environment encompassing the integration of different disciplines of the New Zealand Curriculum with the IWB was created and that this environment did optimise student learning. The convergence of pedagogy and technology in Project ACTIVate emulated the findings of Miller, Glover and 
Averis (2008) in the United Kingdom. Miller et al. (2008) suggest that the framework of Skills, Pedagogy, Opportunity, Reflection and Evolution (SPORE) is central to the effective use of the IWB. This is notable in that the IWB gives an opportunity for the teachers and students 'to use the IWB in a variety of interesting and creative ways, some of which might not have been possible without the IWB' (Miller et al., 2008; p.12). In the IWB environment, the student-teacher partnership needs to place the emphasis on learning with reference to thinking, questioning, constructing knowledge and reflecting. Thus, in the twenty first century multi-modal ways of teaching and learning need to reflect the environment, content presentation, knowledge construction and assessment. The IWB needs to be seen in this light but it is only one aspect of the cognitive environment. Importantly, as teachers are at the forefront in the use of this technology, they are the people who can best explain how they want to interact both locally and globally, within and across classrooms.

As already stated, the decision for Project ACTIVate schools to use action research as a methodology fitted well with the notion of co-learning and learning within a social context. The participants, both teachers and students, found action research nonthreatening and in fact the democratic methodology of action research suited the IWB context well. The simplicity of the cyclical process when linked to the planning, implementing and reflecting helped the teachers to grow as professional educators. However, it is difficult to obtain hard quantitative data in the IWB environment because so much learning and reflecting is just in time learning. Therefore, much reliance needs to be placed on overall teacher judgements as it is the teachers alone who have the opportunity to draw from first hand evidence illustrating multiple sources of IWB/student interactions and performances.

A further result of the project was the fact that teachers were able to look at a bigger picture and encompass Alton-Lee's (2003) ten characteristics of quality education. This was of the utmost importance, because teachers need to be cognisant of informing their practice and be able to link theory to practice. But it is not just the teachers who need to think 'about the bigger picture' (Brown, 2005; p.5) where pedagogy and technology are concerned. There is a real need for the technology companies to listen to the teachers' voices as well and hear what the teachers want to do at the chalk face.

In the final analysis, if the use of IWBs or any other new education technology is concerned with making educational transformations aimed at creating better conditions for learning, then without a doubt the people effects are as important, or perhaps even more important, than the machine effects. New technology on its own is nothing more than a technical object. As the articles about IWBs by the Project ACTIVate schools in a special issue of Computers in New Zealand Schools, 17(3) (2005) indicated, it is the capacity of the teacher to create effective learning environments that will ultimately determine whether IWBs and associated technologies can create better conditions for learning. Therefore, in this global society to capitalise on cohesive learning communities, we need always to be cognisant of the opportunities for maximising student learning outcomes because in the end, we always have to ask, 'if it's not about learning, what should it be about?' (Stoll, Fink \& Earl, 2003).

\section{References}

Alton-Lee, A. (2003). Quality teaching for diverse students in schooling: Best Evidence synthesis. Wellington: Learning Media, Ministry of Education. [verified 7 Jun 2010] http: / / www.educationcounts.govt.nz / publications / series / 2515/5959 
Armstrong, V., Barnes, S., Sutherland, R., Curran, S., Mills, S. \& Thompson, I. (2005).

Collaborative research methodology for investigating teaching and learning: The use of interactive whiteboard technology. Educational Review, 57(4), 457-469.

Biggs, J. \& Collis, K. (1982). Evaluating the quality of learning: The SOLO Taxonomy (Structure of the Observed Learning Outcome). New York: Academic Press.

Brown. M. (2005). Teacher learning: Thinking global, acting local. Computers in New Zealand Schools, 17(1), 3-6.

Cohen, L., \& Manion, L. (1994). Research methods in education. (4th ed.). New York, NY: Routledge.

Duncan, W., Dysart, B., Ryba, K. \& Edwards, T. (2005). Project ACTIVate: Analysing the effects of teaching and learning with interactive whiteboards. Computers in New Zealand Schools, 17(3), 7-10.

Elluminate Live $(2006,2007)$. http: / / www.elluminate.com/ [viewed 26 Feb 2006].

Engles, P., Cairns, B., Lane, J., Scott, B. \& Yelas, J. (2005). Problem-based learning and interactive whiteboards: Effective teaching and learning practices. Computers in New Zealand Schools, 17(3), 15-19.

Fielding, M. \& Bragg, S. (2003). Students as researchers: Making a difference. Sydney: Pearson Publishing.

Gabel, D. (1999). Science. In G. Caweti (Ed.), Handbook of research on improving student achievement (2nd ed.). Virginia: Educational Research Service.

Gilbert, J. (2005). Catching the knowledge wave? Wellington, NZ: New Zealand Council for Educational Research.

Glover, D., \& Miller, D. (2009). Optimising the use of interactive whiteboards: An application of developmental work research (DWR) in the United Kingdom. Professional Development in Education, 35(3), 469-483.

Harpaz, Y. (2003). Teaching and learning in a thinking curriculum. A paper presented at the Navcon2k3 Conference. Adelaide: Australia.

Jonassen, D. H., Howland, J., Morre, J. \& Marra, R. M. (2003). Learning to solve problems with technology - A constructivist perspective (2nd ed.). Upper Saddle River, New Jersey: Pearson Education Inc.

Jonassen, D. H., Peck, K. L. \& Wilson, B. G. (1999). Learning with technology: A constructivist perspective. Upper Saddle River, New Jersey: Prentice Hall, Inc.

Kemmis, S. \& McTaggart, R. (Eds.) (1988). The action research planner (3rd ed.). Victoria: Deakin University.

Kroll, L. R. \& LaBoskey, V. K. (1996). Practicing what we preach: Constructivism in a teacher education program. Action in Teacher Education, 18(2), 63-72. Summarised in ERIC Digest ED426986 [viewed 27 Jun 2004, verified 7 Jun 2010]. http: / / www.eric.ed.gov:80/ ERICDocs / data/ericdocs2sql/content_storage_01/0000019b/80/17/45/cd.pdf

Lave, J. \& Wenger, E. (1991). Situated learning: Legitimate peripheral participation. Cambridge: Cambridge University Press. 
Mehan, H. (1989). Microcomputers in classrooms: Educational technology or social practice? Anthropology and Education Quarterly, 20(1), 4-22.

Miller, D., Glover, D. \& Averis, D. (2008). Enabling enhanced mathematics teaching with interactive whiteboards. [viewed 14 May 2010; 4.8 MB]. http:/ / http:/ / www.keele.ac.uk/media/keele university / fachumsocsci/sclpppp/education/interactivewhiteboard/ncetmreport-1.pdf

Ministry of Education (2006). Enabling the 21st century learner. An e-learning action plan for schools 2006-2010. Wellington, New Zealand: Learning Media Ltd.

Ministry of Education (2001). Digital Opportunities (Digiops) Projects. http: / / www.digiops.org.nz/ [viewed 26 Feb 2009].

RubiStar (2007). Multimedia Project: Constructing new knowledge in the IWB setting. Rubistar for teachers. http: / / rubistar.4teachers.org/ [Viewed 16 May 2007].

Ryba, K. (2005). School-based research on learning communities. Computers in New Zealand Schools, 17(3), 4-6.

Stoll, L., Fink, D. \& Earl, L. (2003). It's about learning (and it's about time). London: RoutledgeFalmer.

Timperley, H. \& Parr, J. (2004). Using evidence in teaching practice: Implications for professional learning. Auckland: Hodder.

Winter, R. (1989). Learning from experience: Principles and practice in action research. London: The Falmer Press.

Janet Yelas, Director of Curriculum and Teacher

St Mary's School, 115 Onewa Road, Northcote

North Shore 0627, New Zealand

Email: janety@sms.school.nz Website: http:/ / sms.school.nz/

Paul Engles, Principal

St Mary's School, 115 Onewa Road, Northcote

North Shore 0627, New Zealand

Email: paule@sms.school.nz Website: http: / / sms.school.nz/ 